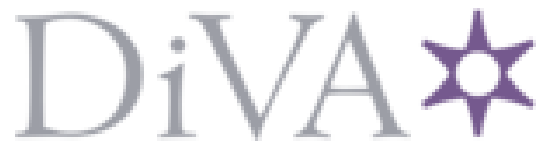

http://www.diva-portal.org

Preprint

This is the submitted version of a paper published in Taxon.

Citation for the original published paper (version of record):

Hawksworth, D., Millanes, A., Wedin, M. (2016)

Fixing the application of the generic name Naematelia (Tremellales) by lectotypification.

Taxon, 65: 1093-1096

https://doi.org/10.12705/655.10

Access to the published version may require subscription.

N.B. When citing this work, cite the original published paper.

Permanent link to this version:

http://urn.kb.se/resolve?urn=urn:nbn:se:nrm:diva-2024 


\title{
Fixing the application of the generic name Naematelia (Tremellales) by lectotypification
}

\section{David L. Hawksworth ${ }^{1,2,3}$, Ana M Millanes ${ }^{4}$ \& Mats Wedin ${ }^{5}$}

1 Departamento de Biología Vegetal II, Facultad de Farmacia, Universidad Complutense de Madrid, Plaza Ramon y Cajal, Madrid 28040, Spain

2 Department of Life Sicences, The Natural History Museum, Cromwell Road, London SW7 5BD, UK

3 Comparative Plant and Fungal Biology, Royal Botanic Gardens, Kew, Surrey TW9 3DS, UK

4 Departamento de Biología y Geología, Física y Química Inorgánica, Universidad Rey Juan Carlos, 28933 Móstoles, Spain

5 Department of Botany, Swedish Museum of Natural History, P.O. Box 50007, Stockholm SE-104 05, Sweden

Author for correspondence: David L. Hawksworth (d.hawksworth@nhm.ac.uk)

\begin{abstract}
The place of publication and typification of the generic name Naematelia is discussed, and $N$. encephala is confirmed as the correct name of the type species of the genus. That name was a replacement name for the earlier $N$. encephaliformis, which is lectotypified by a Willdenow plate; as selection of an epitype cannot be justified at present, a sequenced specimen from Sweden is selected as a reference specimen to represent the molecular application of the name in our sense. As the name $N$. encephala is a sanctioned name, it must be retained over $N$. encephaliformis. The species is fungicolous, widespread, growing mainly on Stereum sanguinolentum on conifers, but also reported on deciduous trees.
\end{abstract}

Keywords: Basidiomycota, epitypification, fungicolous fungi, Stereum, Tremella.

\section{INTRODUCTION}

In the course of molecular phylogenetic studies on fungi in Tremellales, it became clear that the application of the generic name Naematelia was unclear. This issue needed to be resolved in order to enable this name to be taken up for a distinctive clade within the order which has been recognized in recent phylogenetic studies (Liu \& al. 2015, 2016). It emerged that it was necessary to first clarify which species was the type species of the genus, and secondly to determine how that species name should be typified, and if necessary to typify it.

\section{LECTOTYPIFICATION OF THE GENERIC NAME}

The generic designation first appeared in the literature in Fries' contribution to Liljeblad (1816: 608) as "Næmatelia" for two species, N. encephala and N. fragiformis, but with no separate generic diagnosis and no references to previous works; the name was consequently not validly published in that work (Art. 38.1). Valid publication of the name dates from Fries (1818: 370) who provided a separate diagnosis, and included two species: (1) N. encephala based on "Tremella encephala - Pers. 
sy. p. 623. Willd. in Bot. Magaz. $1^{1}$. p. 17. p. 4, f. 14"; and (2) N. tubiformis which was newly described.

Three species were included in the sanctioning work (Fries 1822: 227): (1) N. encephala; (2) N. rubiformis Fr. (almost certainly a lapsus for $N$. tubiformis, which is not otherwise mentioned); and (3) N. nucleata (Schwein.) Fr.

Lloyd (1922: 1149) might at first be considered as having selected $N$. encephala as the type species when he stated ", . . the type species Naemataelia encephala". His intention is, however, unclear as he went on to treat $N$. encephala in a new section of the genus, Encephala, and use the sectional name Naematelia for N. nucleata and N. globulus Corda. Donk (1958a: 236) took this use of the sectional name to suggest Lloyd had apparently taken $N$. nucleata as type, but as that was not one of the species originally included when the name was introduced in 1818 , that selection must be discarded. The first definite choice was that of Clements \& Shear (1931: 342), who selected $N$. encephala, which was one of the two original species, and also one of the three species included in the sanctioning work. That lectotypification was accepted by Donk (1958a: 236; in Farr \& al. 1979: 1143) and we see no reason to reject that choice.

Another generic name involved is Encephalium Link (1816: 33), based on E. aurantiacum Link, and indicated as a synonym of Naematelia by Fries (1822). Link included the single species $E$. aurantiacum Link, which was a replacement name for Tremella encephala Pers. (itself a replacement name for the earlier T. encephaliformis Willd.). As noted by Donk (1958a, b), this means that Encephalium and Naematelia are typonyms (homotypic synomyms). As Fries' genus included the type species of Encephalium in 1818, by the inclusion of $T$. encephala, Naematelia would be a superfluous name to be rejected as illegitimate under Art. 52.1. As Naematelia was adopted in the sanctioning work, however, that name can be retained for use and the earlier unsanctioned Encephalium treated as a homotypic synonym.

Naematelia Fr., Observ. mycol. 2 : 370. 1818 : Fr., Syst. mycol. 2: 227. 1822.

LT: N. encephala (Pers.) Fr. (selected by Clements \& Shear, Gen. fung.: 342. 1931).

(三) Encephalium Link in Mag. Ges. Naturf. Fr. Berlin 7: 3. 1816.

Several orthographic variants of Fries' name are detailed in Donk (1958a): Naematella, Nematelia, Nematella, and Nemathelium. For information on those variants, the reader should refer to his paper.

\section{LECTOTYPIFICATION OF THE TYPE SPECIES}

In introducing the name Tremella encephala, Persoon (1801: 623) referred to Willdenow's plate but did not cite his binomial as a synonym. This name would nevertheless normally be regarded as superfluous and to be rejected as the type of another name was cited in the protologue (Art. 52.2). This is not the case, however, as Persoon's epithet was adopted by Fries in the sanctioning work (Art. 15.1). The plate is part of the original material and so available for lectotypification. Willdenow's material was collected on Pinus sylvestris near Berlin ("In truncis Pini sylvestris inter Bützow \& Pegel prope Berolinum hymene passim"). No original material could be located in B by the first author and R. Lücking, and any that was formerly present would have almost certainly been destroyed in World War II as no fungi remain amongst the remnants of Willdenow's material that still exists in $\mathrm{B}$.

\footnotetext{
${ }^{1}$ This was a lapsus as this paper is in vol. 4 part 1, and not vol. 1 of the journal cited.
} 
We also found that there was no material under the name Tremella encephala amongst Persoon's collections under that name in L (R. Bijmoer, pers. com.) which might have been a candidate lectotype if it could be established as having been studied by Persoon before 1801. Persoon's name, which can be retained over that of Links' as it was sanctioned by Fries (1822), has to be lectotypified by the Willdenow illustration as that is the only original material known to be extant.

In the Willdenow plate the host, which is normally Stereum sanguinolentum, is not visible. The basidiomes are typically a combination of a fleshy-fibrous core formed of host hyphae - surrounded by a gelatinous outer layer, which corresponds to the actual tremellalean fungus. The internal core was recognized as a key feature of the fungus by Lloyd (1922). The restriction of the name to the tremellaceous element is in accordance with Bandoni's (1961) interpretation, but it is not necessary to specify an element in the Willdenow figure as a lectotype as host tissues are not evident. Lectotypification by Willdenow's plate is therefore effected here.

As the macroscopic features shown in the lectotype plate leave no doubt about the application of the name, and there is currently no evidence of cryptic speciation, selection of an epitype cannot be unequivocally justified under the current Art. 9.8. In order to leave no doubt about our application of the name, however, both on the basis of microscopic and molecular data, we follow Ariyawansa \& al. (2014) in selecting a Reference Specimen (RefSpec) for that purpose., If an epitype becomes justifiable in future, and no modern specimen from the Berlin area can be obtained, the RefSpec collection from Sweden could be considered a candidate for a future epitypification.

Roberts (1999) provided microscopic details of the fungus, but was under the impression that the name was invalid as a nomen confusum as it was based on the fungus and its host. However, that statement is not correct, as while names based on discordant elements were to be rejected under the Code up to 1975, that provision was deleted at the Leningrad congress in 1975 (Stafleu \& al. 1978: 57).

Naematelia encephala (Pers.) Fr., Observ. mycol. 2 : 370. 1818 : Fr., Syst. mycol. 2: 227. 1822.

(三) Tremella encephala Pers., Syn. meth. fung. : 623. 1801.

(三) T. encephaliformis Willd. in Bot. Mag. (Römer \& Usteri) 4 (1): 17. 1788.

(झ) Encephalium aurantiacum Link in Mag. Gesell. Naturf. Freunde Berlin 7: 3. 1816.

LT: Willdenow (in Bot. Mag. (Römer \& Usteri) 4 (1): tab. 4 fig 14. 1788, lectotype designated here; MBT 371955).

RefSpec: SWEDEN. Uppland: Österåker-Östra Ryd, Åkersberga, "Röllingby backar", parasitic on Stereum sanguinolentum on cut branches of Pinus sylvestris on the ground, 7 Feb.1988, A. Strid 18486 (S - F169949, reference specimen selected here; GenBank accession number: KU680964).

Willdenow's plate and the element designated as lectotype are shown in Figs 1-2, respectively, while the reference specimen is illustrated in Fig. 3

For information on possible further synonyms see Bandoni (1961), Donk (1966) and Lloyd (1922).

\section{ACKNOWLEDGEMENTS}

We thank Robert Lücking for assistance in searching for Willdenow collections in B and access to the library facilities of the Botanisches Museum in Berlin; Roxali Bijmoer for looking for Persoon material in L, and Jennifer Kearey (Swedish Museum of Natural History) for photographs of the epitype. This 
paper was supported by the Spanish Ministry of Economy and Competitiveness through grants to D. L. Hawksworth (CGL2014-55542), A. Millanes and M. Wedin (CGL2012-40123), and by The Swedish Taxonomy Initiative (Svenska Artprojektet, administered by the Swedish Species Information Centre/ArtDatabanken) through a grant to M. Wedin.

\section{LITERATURE CITED}

Ariyawansa, H.A., Hawksworth, D.L., Hyde, K.D., Maharachchikumbura, S.S.N., Manamgoda, D.S., Thambugala, K.M., Udayanga, D., Camporesi, E., Daranagama, A., Jayawardena, R., Jones, E.B.G., Liu, J.-K., McKenzie, E.H.C., Phookamsak, R., Senanayake, I.C., Shivas, R.G., Tian, Q. \& Xu, J.-C. 2014. Epitypification and neotypification: guidelines with appropriate and inappropriate examples. Fungal Diver. 69: 57-91.

Bandoni, R. J. 1961. The genus Naematelia. Amer. Midl. Naturalist 66: 319-328.

Clements, F.E. \& Shear, C.L. 1931. The Genera of Fungi. New York: H.W. Wilson.

Donk, M.A. 1958a.The generic names proposed for hymenomycetes-VIII. Auriculariaceae, Septobasidiaceae, Tremellaceae, Dacrymycetaceae. Taxon 7: 236-250.

Donk, M.A. 1958b. The generic names proposed for hymenomycetes-VIII. Auriculariaceae, Septobasidiaceae, Tremellaceae, Dacrymycetaceae. Taxon 7: 193-207.

Donk, M. A. 1966. Check list of European hymenomycetous Heterobasidiae. Persoonia 4: 145-335.

Farr, E. R., Leussink J. A. \& Stafleu F. A. (eds.). 1979. Index Nominum Genericorum (Plantarum). Vol. II. Eprolithus-Peersia. [Regnum Veg. 101.] Utrecht: Bohn, Scheltema \& Holkema.

Fries, E.M. 1818. Observationes mycologicae. Vol. 2. Copenhagen: Gerh. Bonnier.

Fries, E.M. 1822. Systema mycologicum. Vol. 2 (1). Lund: Berlingiana.

Liljeblad, S. 1816. Utkast til en Svensk flora. $3^{\text {rd }}$ edn. Uppsala: Ziepel \& Palmblad.

Link, H.F. 1816. Observationes in ordines plantarum naturales. 2. Mag. Gesell. Naturf. Freunde Berlin 8: $25-45$.

Liu, X.-Z., Wang, Q.-M., Theelen, B., Groenewald, M., Bai, F.-Y. \& Boekhout T. 2015. Phylogeny of tremellomycetous yeasts and related dimorphic and filamentous basidiomycetes reconstructed from multiple gene sequence analyses. Stud. Mycol. 81: 1-26.

Liu, X.-Z., Wang, Q.-M., Göker, M., Groenewald, M., Kachalkin, A.V., Lumbsch, H.T., Millanes, A.M., Wedin, M., Yurkov, A. M., Boekhout T. \& Bai, F.-Y. 2016. Towards an integrated phylogenetic classification of the Tremellomycetes. Stud. Mycol. 81: 85-147.

Lloyd, C.G. 1922. The genus Naematelia. Mycol. Notes Lloyd Libr. Mus. 67: 1149-1151.

Roberts, P. 1999. British Tremella species II: T. encephala, T. steidleri \& T. foliacea. Mycologist 13: 127-131.

Stafleu, F.A., Demoulin V., Greuter, W., Hiepko, P., Linczevski, I.A., McVaugh, R., Meikle, R.D., Rollins, R.C., Ross, R., Schopf, J.M. \& Voss, E.G. (eds.). 1978. International Code of Botaical Nomenclature adopted by the Twelfth International Botanical Congress, Leningrad, July 1975. [Regnum Veg. 97.] Utrecht: Bohn, Scheltema \& Holkema. 
Willdenow, L. 1788. Observationes botanicae. Bot. Mag. (Römer \& Usteri) 4 (1): 7-19. 